\title{
Equine infectious anemia in the western region of Rio Grande do Sul, Brazil
}

\section{Cristiane Santin Barzoni ${ }^{1,3}$ Daniele Martinez Pereira Nogueira ${ }^{2}$ Gisele Dias Marques ${ }^{1}$ Gustavo Nogueira Diehl ${ }^{3}$ Débora da Cruz Payão Pellegrini ${ }^{1}$ Mário Celso Sperotto Brum ${ }^{1,2^{*}}$.}

\author{
${ }^{1}$ Programa de Pós-graduação em Ciência Animal, Universidade Federal do Pampa (UNIPAMPA), Campus Uruguaiana, 97508-000, Uruguaiana, \\ RS, Brasil. E-mail: mariobrum@unipampa.edu.br. \\ ${ }^{2}$ Laboratório de Virologia, Curso de Medicina Veterinária, Universidade Federal do Pampa (UNIPAMPA), Campus Uruguaiana, Uruguaiana, \\ RS, Brasil. \\ ${ }^{3}$ Programa Estadual de Sanidade Equina (PESE), Defesa Sanitária Animal, Secretaria de Agricultura, Pecuária e Irrigação (DAS/SEAPI), Porto \\ Alegre, RS, Brasil.
}

\begin{abstract}
This study aimed to characterize the outbreaks of equine infectious anemia (EIA) identified, between the years 2009 and 2015 , in the western region of the state of Rio Grande do Sul, Brazil. We identified 26 positive horses on 24 properties. Each positive property was considered an outbreak of the disease. The diagnoses were made using the agar gel immunodiffusion (AGID) test as a part of the sanitary checks conducted during animal transportation or certification of the horse's sanitary status. The positive properties included farms or horse barns, and the infected animals were used for ranch work, sports, or reproduction. One outbreak was identified in animals that were being illegally transported from Argentina to Brazil. Fifteen outbreaks occurred on properties that were not registered with the Official Veterinary Service (OVS). Eleven outbreaks were identified in urban areas and 13 in rural areas. Twelve of the 24 outbreaks were diagnosed in 2015 alone, nine of which occurred in São Borja county. On two properties, a diagnosis could not be confirmed with a retest; therefore, these outbreaks were discharged. During sanitation checks on three properties, 12 additional positive animals were identified among a population of 1,108 susceptible animals. Based on these findings, we concluded that a subclinical form of the infection is present in that area, which is linked to properties that are not registered with the OVS, and that animals which are transported illegally across international borders represent a potential risk.
\end{abstract}

Key words: transboundary disease, illegal transport, EIA, passive surveillance, virus.

Anemia infecciosa equina na região oeste do Estado do Rio Grande do Sul, Brasil

RESUMO: O objetivo do estudo foi caracterizar os focos de EIA identificados, entre 2009 e 2015, na região oeste do estado do Rio Grande do Sul, Brasil. Inicialmente foram identificados 26 equinos positivos em 24 propriedades, sendo que cada propriedade foi considerada um foco. Os diagnósticos foram realizados por imunodifusão em gel de ágar (AGID) na ocasião do transporte ou como medidas sanitárias, em casos de vínculo com animais infectados ou para fim de certificação do status sanitário. Um foco foi identificado em animais transportados ilegalmente da Argentina para o Brasil. Os estabelecimentos positivos eram fazendas ou estábulos e os animais infectados utilizados para trabalho, esporte ou reprodução. Quinze focos ocorreram em propriedades não cadastradas no SVO. Onze focos localizaram-se na zona urbana e 13 em propriedades rurais. Somente no ano de 2015 foram diagnosticados 12 dos 24 focos, sendo que no munícipio de São Borja ocorreram nove surtos neste período. Em duas propriedades o resultado inicial não foi confirmado no reteste, fazendo com que estes focos fossem encerrados imediatamente. Em três propriedades, durante o saneamento, identificou-se outros 12 animais positivos em três propriedades, de uma população de 1.108 susceptiveis. Assim sendo, pode-se concluir que a infecção que está presente na região, ocorre de maneira subclínica, associada a propriedades não cadastradas no SVO e animais transportados de forma ilegal, inclusive transporte internacional ilegal.

Palavras-chave: cavalo, transporte ilegal, EIA, vigilância passiva, vírus.

\section{INTRODUCTION}

Equine infectious anemia (EIA) is a disease that affects equines, mules, and donkeys worldwide (COOK et al., 2013; OIE, 2016). The EIA-causing virus (EIAV) belongs to the Retroviridae family,
Lentivirus genus. It is characterized by an RNA genome, and is surrounded by a conic capsid and an external lipoprotein envelope with a circumference of $115 \mathrm{~nm}$ (ISSEL et al., 2014). During its replication, the virus inserts the viral genome into the cellular genome and produces a persistent infection. The EIAV 
can infect monocytes and macrophages; however, the production of infectious particles occurs especially in macrophages or dendritic cells (ISSEL et al., 2014).

The clinical signs of infection are nonspecific and are related to the levels of viremia. They can arise in an acute or chronic form, and include febrile episodes, thrombocytopenia, and anemia. However, most animals develop a silent form of the infection (ISSEL et al., 2014). Transmission occurs mainly through mechanical vectors (Tabanus spp., Hybomitra spp., and Stomoxys spp.) and by iatrogenic routes, such as syringes, needles, and surgical equipment (ISSEL \& FOIL, 2015). Humid or marshy environments associated with hot weather favor vector multiplication and are predisposing factors for dissemination of the virus (ISSEL \& FOIL, 2015). The viremia marked by febrile episodes is associated with an increased transmission potential (COOK et al., 2013).

In Brazil, while the National Program for Equine Health (PNSE) by the Ministério da Agricultura, Pecuária e Abastecimento (MAPA) regulates the control of EIA, the states are permitted to adopt individual legislation. Official diagnosis is made using agar gel immunodiffusion (AGID or Coggins test) in laboratories certified by MAPA (BRASIL, 2004). The EIAV infection is present in various regions of Brazil, and the prevalence is variable (REBELATTO et al., 1992; SANTOS et al., 2001; ALMEIDA et al., 2006; FREITAS et al., 2015). In 2013, Rio Grande do Sul (RS) had roughly 500,000 equines, distributed on more than 103,000 properties, and the animals were used mainly for sports, work, and reproduction (COSTA et al., 2013). This study aimed to characterize the EIA cases diagnosed in the western region of RS by analyzing the data for outbreaks that occurred between the years 2009 and 2015 and reported to the Official Veterinary Service (OVS).

\section{MATERIALS AND METHODS}

The official notification and communication forms (FORM IN and FORM COM, respectively), and the test reports for cases of EIA diagnosed in the municipalities of Barra do Quaraí, Itaqui, Maçambará, São Borja, and Uruguaiana between 2009 and 2015 were evaluated. The data for each case were obtained from the Secretaria da Agricultura, Pecuária e Irrigação (SEAPI) of RS, Brazil. Serum samples were tested using AGID, in accordance with the manufacturer's instructions, to detect EIAV anti-p26 antibodies (Bruch Laboratory, São Paulo, Brazil). This is the official test used in Brazil and is considered reliable for detecting infected horses (OIE, 2016). All samples were tested in certified laboratories that were previously approved by the National Reference Laboratory via organized proficiency testing (BRASIL, 2004). Additionally, wherever it was possible, we consulted with the laboratories, owners/producers, and veterinarians to obtain information about the property, animals, and sanitary procedures. The collected information was tabulated using Microsoft Excel (Microsoft Office 2010), and was subsequently analyzed.

\section{RESULTS}

Twenty-four outbreaks of equine EIA were found between the years 2009 and 2015 in four of the five municipalities studied: Uruguaiana (seven), Itaqui (four), Maçambará (one), and São Borja (12) (Figures 1 and 2). Only horses (Equus cabalus) were infected, and we considered each property that presented with a positive animal to represent an outbreak. However, 12 outbreaks occurred in 2015 alone, nine of which occurring in São Borja alone. Barra do Quaraí had no reported cases of EIA during this period.

Initially, 26 horses were infected; two properties/outbreaks had two positive animals each, while the other 22 outbreaks had only one infected horse each. Of the 1,108 susceptible animals present on all the affected properties, only four were donkeys, and the remaining were horses. Serum diagnosis was made using AGID in laboratories certified by MAPA, though none of the animals presented with any clinical signs that would suggest an EIAV infection. The primary reasons for requesting the test included requirement for transport (20 cases), previous contact with positive animals (three cases), and sanitary status evaluation (one case). Among the 20 animals that were transported, six horses were commercialized, eight attended sporting events and agglomerations, and in six cases it was not possible to identify the reason for transport. The age of the EIAV-positive horses ranged from two to 21 years, and while 14 were Crioulo horses, 12 were of a mixed breed.

One outbreak originated in animals transported illegally from Argentina to the Itaqui municipality in Brazil, through the Uruguay River. In this episode, seven animals were being transported illegally. Tests and detection of EIA were carried out by the Brazilian authorities. Two animals had a positive serological response to the EIAV. The other 23 positive properties were temporary stables (seven), cattle farms (eight), and farms for breeding and trading 


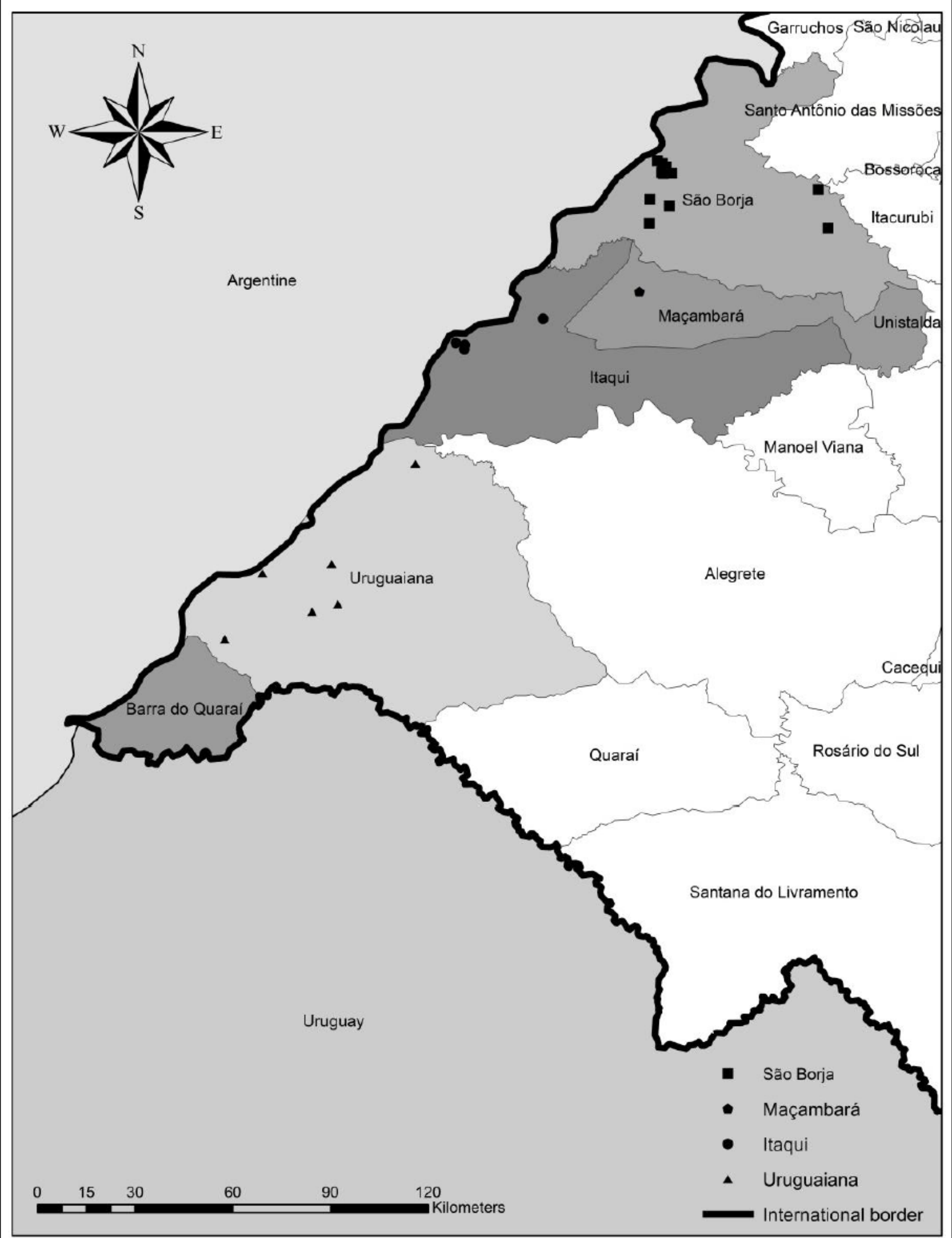

Figure 1 - Distribution and geolocalization of equine infectious anemia (EIA) outbreaks in the west region of Rio Grande do Sul State, Brazil, from 2009 to 2015 .

Ciência Rural, v.48, n.6, 2018. 
horses (eight). The positive properties were located in both urban (11/24) and rural areas (13/24). However, it must be noted that six of the nine outbreaks identified in São Borja in 2015 occurred in urban areas. The affected herd sizes are presented in figure 2 .
After confirming EIA, four property owners requested a retest. Retesting was performed by the certified laboratory using the same serum samples. In two cases the positive results were reconfirmed, while in the other two cases a retest was not possible

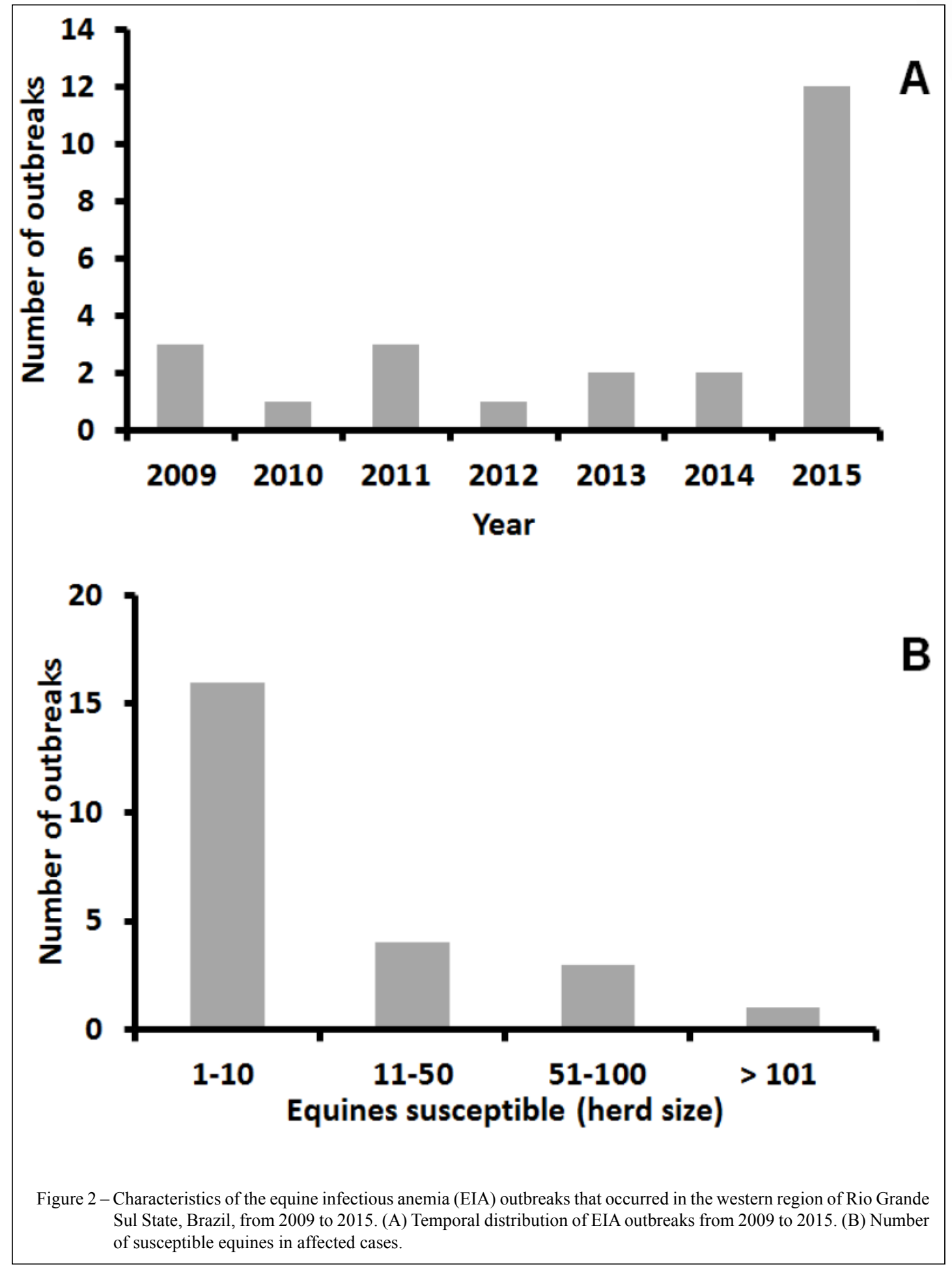

Ciência Rural, v.48, n.6, 2018. 
due to insufficient volume of the collected samples. A counterproof, where a second blood sample is collected by the OVS and is tested by the National Reference Laboratory, was requested by five property owners. In three outbreaks, the initial results from a certified laboratory were confirmed. However, in another two cases, results of the retests were divergent; and therefore, the animals were considered negative and the cases were closed in accordance with national legislation (BRASIL, 2004). Discrepancies in the results are rarely observed, and could be due to misidentification of the horses (ISSEL \& COOK, 1993).

The official sanitation procedure, which involves the property's interdiction, the sacrifice of positive animals, and testing of every other animal, was conducted on 16 of the 24 properties. In six cases, sanitation procedures were not performed according to the current legislation, and two cases were dismissed following the results of the retest. During the sanitation checks, 1,108 contact animals were serologically tested. Seven properties presented with only one positive animal, and sanitation procedures were concluded without any further measures. In three outbreaks, there were additional positive animals, which included 10 out of 39 equines on a farm, and in two cases, only one additional horse on each property. The sanitation procedure in Brazil is conducted with two serum tests, performed at 60-day intervals; all positives horses were detected with the first blood test.

In three cases, it was possible to identify the source of infection. Two horses tested positive after they lived with an infected horse identified in a previous outbreak, and syringes and needles had been shared for drug administration. In the other two outbreaks, interaction with infected animals was reported, though it was not possible to suggest a method of transmission. In another case that arose two years after the property was purchased and the animals were tested for trading, it was not possible to track the history of the positive animal. In 19 outbreaks, it was not possible to identify the source of infection or the form of disease transmission, but it was affirmed that in at least 12 of these outbreaks, there was illegal movement of horses. This illegal movement was due to the property not being registered with the OVS, which resulted in not having the required documentation for transport (GTA Animal Transportation Guide).

\section{DISCUSSION}

Twenty-four outbreaks of EIA that occurred in five years in municipalities in the western region of RS, Brazil have been described and characterized. The official data show that the EIAV is present among the equine population and suggests a low prevalence level. In 2013, the state OVS conducted an official serological survey for EIA and considered only the properties registered with the OVS. The results indicated a prevalence of less than $0.3 \%$ (SEAPA, 2014). However, among the described cases, 15 outbreaks occurred on non-registered properties or properties that had non-registered horses. In these cases, illegal movement of animals had taken place at some time, without proper transport documentation; and therefore, without testing for EIA. These findings indicated that the illegal traffic of animals is an extremely important route for dissemination of infections in horses, and this was evident in the EIA outbreaks (DOMINGUEZ et al., 2016).

In addition, among these 15 non-registered properties, 11 outbreaks were identified on properties located in urban areas, which are typically used for maintenance of sports horses (ALMEIDA \& SILVA, 2010). Owners keep a few animals, usually with no veterinary assistance and under very poor biosecurity and sanitary conditions. Although, legislation states that every animal owner and horse keeper is obliged to register with the OVS (RIO GRANDE DO SUL, 2010), these urban area owners do not consider themselves to be producers; and therefore, do not follow rules. Moreover, in towns, there is a population of marginal horses, used as draft power, that are not registered with the OVS and are likely to be infected with the EIAV (ALMEIDA et al., 2006; CUTOLO et al., 2014). These uninspected animals were not evaluated in this study.

The increasingly strict horse transport laws have resulted in a significant rise in the registration of new producers; and thereby, in the number of GTAs generated (SEAPA, 2014). This has led to an increase in the number of EIA cases diagnosed. Prevalence of EIA infection in Brazil varies depending on the region, and several studies have indicated these differences (REBELATTO et al., 1992; SANTOS et al., 2001; ALMEIDA et al., 2006; COSTA et al., 2013; FREITAS et al., 2015). Usually, the northern states and the Pantanal region have higher prevalence compared to the other Brazilian regions, which is a consequence of several factors, including previous prevalence, animal movement, rigid control measures, presence of vectors, and official programs for control (ALMEIDA et al., 2006).

The average of two outbreaks/year diagnosed between 2009 and 2014 corresponds to $50 \%$ of the total outbreaks described in the study 
period. However, in 2015 alone, 12 outbreaks were identified, nine of which occurring in São Borja. It has not been possible to identify the reason for this higher incidence of EIA outbreaks in São Borja. Given the increase in traffic surveillance, there could be additional undetermined factors that contributed to the significant increase in EIA outbreaks in this municipality. Additionally, due to the presence of the OVS, it has been a challenge to collect truthful and trustworthy data from the producers. A more detailed investigation of the outbreaks and the genetic characterization of the circulating virus may offer information about the samples present in the area and its possible variations (DOMINGUEZ et al., 2016; TIGRE et al., 2017).

The studied area is the international border of Brazil, Argentina, and Uruguay, and illegal movement of animals between these countries is widely reported. This region, formed by these three countries, has similar productive traits, and horses are used for work with cattle and sheep (COSTA et al., 2013). Moreover, there is a strong production of horses in this area for breeding and sports (COSTA et al., 2013). An outbreak originated from two positive horses, from a total of seven, that were smuggled from Argentina (through the Uruguay River) and seized in Itaqui. While the prevalence of EIAV in Argentina and the border area with Brazil is higher than 10\% (DE LA SOTA et al., 2005; RICOTTI et al., 2016), Uruguay has not registered any EIA outbreaks since 2007 (OIE, 2016). Illegal international transportation of animals and animal by-products has been responsible for the transmission of various diseases around the world (BOLFA et al., 2016; DOMINGUEZ et al., 2016). More specifically, the recent EIA outbreaks in Romania, Ireland, and Belgium were f related to the illegal movement of animals among these countries (BOLFA et al., 2016; DOMINGUEZ et al., 2016). Similarities in livestock production and equestrian sports among countries favors the movement of animals and their by-products. Consistent with earlier reports, we also found that this movement of animals leads to transmission of diseases.

Iatrogenic or mechanical transmission by vectors (Tabanus spp., Hybomitra spp., and Stomoxys spp.) are the most important forms of EIAV transmission (ISSEL \& FOIL, 2015). In one outbreak (\#3), it was possible to identify shared syringes and needles as the routes of transmission, while in two other outbreaks (\#10 and \#17) there were periods of time when the horses lived with EIAV-positive horses, though it was not possible to identify how the transmission occurred. None of the routes of transmission can be discounted since vectors were present in that area. Sanitary measures made it possible to control the dissemination of the virus to the rest of the herd. Among the outbreaks that had a higher number of susceptible animals, only three had additional horses that tested positive for the EIAV. Both outbreaks \#10 and \#17 had only one positive horse each. However, in outbreak \#14, 10 other horses tested positive among a herd of 40 animals, but the routes of transmission were not identified in these cases. The number of positive animals suggested that either the infection was present in the animals on the property for a long time or that the animals were exposed to the same source of infection. However, in general, the low number of positive animals in the same outbreak strengthens the possibility that the horses were illegally transported on a frequent basis, which decreased the incidences of transmission.

Animals serologically diagnosed using AGID appeared outwardly healthy, with no clinical signs. A considerable number of the EIAV hosts stay asymptomatic and are considered an important source of infection, because they appear normal, attend events, and are most easily traded (ISSEL et al., 2014; BOLFA et al., 2016; RICOTTI et al., 2016). Passive surveillance was fundamental in the diagnosis and control of the EIAV in this region of RS, and 23 of the 24 related cases were detected by this method. An increase in the strictness of the state legislation in 2013 (RIO GRANDE DO SUL, 2013) contributed to an increased number of registered properties, and consequently, the number of animals evaluated. Although, active surveillance helped identify only one outbreak involving animals that were smuggled from Argentina to Brazil, it is still important to perform surveillance of and control animal movement in order to curb the transmission of the EIAV.

We have demonstrated that the EIAV is circulating in the regional horse population and is associated with small herds, illegal transportation, and producers that are not registered with the OVS. All data was obtained from the Veterinary Service's forms and documents. However, information provided by owners and producers can be inaccurate, and thus can result in some misinformation. Another limitation of this retrospective analysis was the lack of virus identification. Due to the proximity of international borders and illegal animal transport, it is possible that more than one EIAVtype is circulating in the region. Efforts to provide information regarding viral identity should be made.

Despite the low number of EIAV-positive animals in the region, an educational campaign should 
be launched to increase owner awareness regarding the risk of illegal transport, need for registration with the OVS, and routes of virus transmission. Improving the level of knowledge and increasing the rigor of inspections will contribute to the eradication and elimination of this disease among the equine population. Additionally, the fact that other infectious agents can cross international borders via animal smuggling should not be ignored.

\section{CONCLUSION}

We have demonstrated the presence of EIAV infection in the municipalities of Itaqui, Maçambará, São Borja, and Uruguaiana in the state of RS. The infection have low prevalence, is present in the silent form, and was detected mainly by passive surveillance due to the monitoring of sanitary conditions during transport. One case was related to the illegal transport of horses. The increasingly strict regulations ensure that new producers and breeders are included in the official system for monitoring sanitary conditions, which in turn enables the detection of new cases of EIA. Since the prevalence of the infection is low, any possible virus eradication in the herd will only be effective with the cooperation of every sector involved, including the producers and the OVS.

\section{DECLARATION OF CONFLICTING INTERESTS}

The authors declare that they have no potential conflicts of interest with respect to the research, authorship, and/or publication of this article.

\section{ACKNOWLEDGEMENTS}

The authors thank the Secretaria de Agricultura, Pecuária e Irrigação (SEAPI/RS) for the availability of the data and the Programa de Pós-Graduação em Ciência Animal, Universidade Federal do Pampa (UNIPAMPA), Uruguaiana, Brasil, for the financial support.

\section{REFERENCES}

ALMEIDA, F.Q.; SILVA, V.P. Scientific progress in equine production at 1 st decade of the XXI century. Revista Brasileira de Zootecnia, v.39, p.119-129, 2010. Available from: <http://www.scielo.br/ scielo.php?script=sci arttext\&pid=S1516-35982010001300014> Accessed: Feb. 20, 2016. doi: 10.1590/S1516-35982010001300014.

ALMEIDA, V.M.A. et al. Equine infectious anemia: prevalence in working equids of livestock herds, in Minas Gerais, Brazil. Arquivos Brasileiro de Medicina Veterinária e Zootecnia, v.58, n.2, p.141-148, 2006. Available from: <http://www.scielo.br/ scielo.php?script $=$ sci arttext\&pid $=$ S0102-09352006000200001 $>$. Accessed:Nov.20,2016.doi: 10.1590/S0102-09352006000200001.
BOLFA, P. et al. Equine infectious anaemia in Europe: Time to reexamine the efficacy of monitoring and control protocols? Equine Veterinary Journal, v.48, n.2, p.140-142, 2016. Available from: $<$ https://onlinelibrary.wiley.com/doi/abs/10.1111/evj.12466>. Accessed: May 28, 2016. doi: 10.1111/evj.12466.

BRASIL. Normas para prevenção e o controle da anemia infecciosa equina - A.I.E. Instrução Normativa $n^{\circ} 45$, de 15 de julho de 2004. Secretaria de Defesa Agropecuária, Ministério da Agricultura, Pecuária e Abastecimento. Diário Oficial da República Federativa do Brasil, 2004. Available from: <http:// www.agricultura.rs.gov.br/upload/arquivos/201701/05142347pese-in-45-2004.pdf>. Accessed: Jan. 07, 2016.

COOK, R.F. et al. Equine infectious anemia and equine infectious anemia virus in 2013: a review. Veterinary Microbiology, v.167, n.1-2,p.181-204, 2013. Available from: < https://www.sciencedirect. com/science/article/pii/S0378113513004707?via\%3Dihub>. Accessed: Jun. 01, 2016. doi: 10.1016/j.vetmic.2013.09.031.

COSTA, E. et al. Horse-rearing in Rio Grande do Sul. A Hora Veterinária, v.33, p.45-49, 2013. Available from: <http://www. agricultura.rs.gov.br/upload/arquivos/201612/02101333-inftec50-panorama-da-equinocultura-no-rio-grande-do-sul.pdf $>$. Accessed: Jan. 08, 2016.

CUTOLO, A.A. Equine infectious anaemia in urban area horses of Monte Mor municipality, Campinas metropolitan area, São Paulo State, Brazil. Semina: Ciências Agrárias, v.35, n.3, p.1377-1382, 2014. Available from: <http://www.uel.br/revistas/uel/index.php/ semagrarias/article/view/15266>. Accessed: Fev. 10, 2016. doi: 10.5433/1679-0359.2014v35n3p1377.

DE LA SOTA, M.D. et al. Contribution to determine the prevalence of equine infectious anemia in Argentina. Revista Colégio de Médicos Veterinários de la Provincia de Buenos Aires, v.10, p.52-60, 2005. Available from: <http://www.senasa.gob.ar/sites/ default/files/ARBOL_SENASA/ANIMAL/EQUINOS/PROD_ PRIMARIA/SANID\%20ANIM/EES/ANEMIA INFECC/file909anemia_infecciosa.pdf $>$. Accessed: Jan. 08, $201 \overline{7}$.

DOMINGUEZ, M. et al. Equine disease events resulting from international horse movements: systematic review and lessons learned. Equine Veterinary Journal, v.48, n.5, p.641-653, 2016. Available from: < https://onlinelibrary.wiley.com/doi/abs/10.1111/ evj.12523>. Accessed: Jan. 08, 2017. doi: 10.1111/evj.12523.

FREITAS, N.F.Q.R. et al. Equine infectious anaemia on Marajo Island at the mouth of the Amazon river. Pesquisa Veterinária Brasileira, v.35, n.12, p.947-950, 2015. Available from: <http:// www.scielo.br/scielo.php? script $=$ sci_arttext\&pid $=S 0100$ 736X2015001200947>. Accessed: Jan. 08, 2017. doi: 10.1590/ S0100-736X2015001200002.

ISSEL, C.J.; COOK, R.F. A review of techniques for the serologic diagnosis of equine infectious anemia. Journal of Veterinary Diagnostic Investigation, v.5, n.1, p.137-141, 1993. Available from: <http://journals.sagepub.com/doi/abs/1 0.1177/104063879300500136>. Accessed: Jan. 07, 2017. doi: $10.1177 / 104063879300500136$.

ISSEL, C.J. et al. Equine infectious anemia in 2014: live with it or eradicate it? Veterinary Clinics North America: Equine Practice, v.30, n.3, p.561-577, 2014. Available from: $<$ https://www.sciencedirect. com/science/article/pii/S0749073914000601?via\%3Dihub>. Accessed: Feb. 15, 2016. doi: 10.1016/j.cveq.2014.08.002.

Ciência Rural, v.48, n.6, 2018. 
ISSEL, C.J.; FOIL, L.D. Equine infectious anaemia and mechanical transmission: man and the wee beasties. Scientific and Technical Review, v.34, n.2, p.513-523, 2015. Available from: <http://web.oie. int/boutique/extrait/18issel513523.pdf $>$. Accessed: Jul. 13, 2016.

OIE. World Animal Health Information Database (WAHIS) Interface. Available from: <http://www.oie.int/wahis 2/wah/ health_v7_en.php>. Accessed: Sept. 26, 2016.

REBELATTO, M.C. et al. Serological diagnosis of equine infectious anaemia virus infection in the central region of the Rio Grande do Sul state. Ciência Rural, v. 22, n.2, p.179-196, 1992. Available from: <http://www.scielo.br/scielo.php?script=sci artt ext\&pid=S0103-84781992000200012>. Accessed: Jan. 08, 2016. doi: $10.1590 / \mathrm{S} 0103-84781992000200012$.

RICOTTI, S.etal. Serologically silent, occult equine infectious anemia virus (EIAV) infections in horses. Veterinary Microbiology, v.187, n.1, p.41-49, 2016. Available from: $<$ https://www.sciencedirect.com/ science/article/pii/S0378113516300608?via\%3Dihub>. Accessed: Jan. 07, 2017. doi: 10.1016/j.vetmic.2016.03.007 .

RIO GRANDE DO SUL. Decreto n0 50.072, de 18 de fevereiro de 2013. Diário Oficial do Estado do Rio Grande do Sul, Porto Alegre, RS. Available from: <http://www.al.rs.gov.
br/filerepository/repLegis/arquivos/DEC\%2050.072.pdf>. Accessed: Jan. 07, 2016.

RIO GRANDE DO SUL. Lei n0 13.467, de 15 de junho de 2010. Diário Oficial do Estado do Rio Grande do Sul, Porto Alegre, RS. Available from: <http://www.agricultura.rs.gov.br/upload/ arquivos/201607/19124740-13-467-de-15-06-2010-codigosanitario-rs.pdf>. Accessed: Jan. 07, 2016.

SANTOS, R.M.L. et al. Frequency of equine infectious anemia in the State of Acre, Brazil, from 1986 to 1996. Arquivos Brasileiros de Medicina Veterinária e Zootecnia, v.53, n.3, p.310-315, 2001. Available from: $<$ http://www.scielo.br/scielo.php?script=sci artt ext\&pid=S0102-09352001000300007>. Accessed: Jan. 08, 2016. doi: 10.1590/S0102-09352001000300007.

SEAPA. Inquérito soroepidemiológico da anemia infecciosa equina no Estado do Rio Grande do Sul. Seção de Epidemiologia e Estatística. Secretaria de Agricultura, Pecuária e Agronegócio. 2014.

TIGRE, D.M. et al. Characterization of isolates of equine infectious anemia virus in Brazil. Archives of Virology, v.162, n.3, p.873-877, 2017. Available from: $<$ https://link.springer.com/article /10.1007\%2Fs00705-016-3172-5>. Accessed: Jun. 28, 2017. doi: $10.1007 / \mathrm{s} 00705-016-3172-5$. 